(OL-1) - Interviu $\mathrm{z}$ Olehom Lyashkom. URL: https://ukr.segodnya.ua/interview/intervyu-s-olegom-lyashko-ya-schitayuchto-nado-legalizovat-oruzhie-i-dat-vozmozhnost-ukraincam-sebyazashchishchat-760489.html

(OL-2) - Interviu $\mathrm{z}$ Olehom Lyashkom. URL: https://glavcom.ua/interviews/oleg-lyashko-vpershe-viznayu-peredviborami-mi-domovilis-z-lovochkinim-inshogo-vihodu-prosto-ne-bulo371621.html

(AP) - Interviu $\mathrm{z}$ Andriiem Parubiiem. URL: https://www.ukrinform.ua/rubric-polytics/2211881-andrij-parubij-golovaverhovnoi-radi-ukraini.html

(AS) - Interviu $\mathrm{z}$ Andriiem Sadovym. URL: http://www.dw.com/uk/a-40623655

(IuT-1) - Interviu $\mathrm{z}$ Yuliieiu Tymoshenko. URL: https://tsn.ua/politika/interv-yu-yuliyi-timoshenko-dlya-tsn-879420.html (IuT-2) - Interviu $\mathrm{z}$ Yuliieiu Tymoshenko. URL: http://bulvar.com.ua/gazeta/archive/s635/lider-partii-batkivshchina-julijatimoshenko-janukovichu-za\%C2\%A0menja-sudba-otomstila-bolshej-karychem $\% \mathrm{C} 2 \%$ A0poterja-rebenka-on-zasluzhit-ne-mog.html

Дата надходження до редакції - 17.09.2018 p.
Дата затвердження редакцісю - 22.10.2018 p.

УДК 811.161.2:81`42

DOI: https://doi.org/10.17721/APULTP.2018.37.89-105

Oleksandr V. Levko

\title{
SHAPING OF THE AXIOLOGICAL STATUS OF TOMOS IN UKRAINIAN RELIGIOUS MEDIA DISCOURSE IN THE LIGHT OF COGNITIVE LINGUISTICS AND RHETORIC
}

Abstract. The paper is focused on the cognitive mechanisms underlying the construction of axiological status of Tomos and autocephaly of the Ukrainian Orthodox Church in Ukrainian religious media discourse of the last few months from the standpoint of cognitive linguistics and 
rhetoric. The data used for the study are interviews, announcements and other media texts of the UOC (MP) and UOC (KP) leaders and spokesmen, published on respective official websites of each jurisdiction in 2018.

As a result of our study, it was found out that discussions around Tomos and autocephaly gave birth to new allusion-based phraseological units in Ukrainian media space, while also actualizing the use of religious terms which had been previously unknown to average citizens, such as "Tomos", "autocephaly", "canonicity", "Eucharistic communication", "Ecumenical Patriarch" etc. In the media context, these specific terms of the Church law have acquired axiological connotations, turning into axiologems and anti-axiologems. It was also revealed that the argumentation of the positive / negative axiological status of Tomos and autocephaly in Ukrainian religious mass media largely relies on cognitive metaphors and metonymies. In the media context, these cognitive mechanisms of knowledge categorization are of great importance in swaying the public opinion and affecting the value system of the audience. In the texts under study, the most common cognitive metaphors are "Church is body", "Church leaders are doctors", "Intra-Orthodox relations are war", "Intra-Orthodox relations are play", while the most prominent cognitive metonymy is geographical metonymy, whereby the agency is transferred to location. The most productive source domains for the metaphors, which serve to express the evaluation of current processes in the Church, turn out to be human body, medicine, war, play and crime. Decisions of Church leaders regarding Tomos are conceptualized as right or wrong diagnosis and treatment for an illness, expansionist policies or war for peace, raider attack or fair / unfair play. In the media texts produced by both sides, negative connotations are also conveyed via geographical metonymy, when the Constantinople Patriarchate is substituted for by Fanar or Istanbul, whereas the Moscow Patriarchate is referred to as Moscow or Kremlin. We have come to the conclusion that cognitive metaphors and metonymies in Ukrainian religious media discourse are used with the purpose of increasing the persuasive effect of the text and swaying the audience towards adopting the viewpoint of the addresser.

Keywords: cognitive metaphor, cognitive metonymy, religious media discourse, axiologeme, values, Tomos, autocephaly.

Information about author: Levko Oleksandr Vadymovych - PhD; associate professor of the department of general linguistics, classical philology and Hellenic studies; Institute of philology; Kyiv national Taras Shevchenko university.

E-mail: o.levko@knu.ua. 


\section{ФОРМУВАННЯ АКСІОЛОГІЧНОГО СТАТУСУ ТОМОСУ В УКРӒ̈НСЬКОМУ РЕЛІГІЙНОМУ МЕДІАДИСКУРСІ У СВІТЛІ КОГНІТИВНОЇ ЛІНГВІСТИКИ ТА РИТОРИКИ}

Анотація. У статті досліджуються когнітивні механізми формування аксіологічного статусу Томосу й автокефалії Украӥнської православної церкви в сучасному украӥнському релігійному медіадискурсі під кутом зору когнітивної лінгвістики та риторики. Матеріалами дослідження стали інтерв'ю, заяви та інші медіатексти очільників та спікерів украӥнських православних цуерков, щзо опубліковані на відповідних офіц̧ійних сайтах кожної церковної юрисдикиї за 2018 p.

У результаті аналізу встановлено, щзо дискусії в українських ЗМІ навколо питань надання Томосу Украӥнській православній цееркві Константинопольським патріархатом зумовили появу нових фразеологізмів, наприклад "Страсті за Томосом", "Томос Шрьодінгера", "Томос і Джері", та актуалізували вживання нових для пересічної аудиторії понять $і$ слів в украӥнському медіапросторі, зокрема "томос", "автокефалія", "канонічність", "євхаристичне спілкування", "вселенський патріарх" тощуо. Визначено, щуо нові для українських медіа поняття й лексеми отримали аксіологічне забарвлення у ЗМI, перетворивиись із термінів цзерковного права на аксіологеми або антиаксіологеми. Було також визначено, щуо в основі аргументації позитивного / негативного аксіологічного статусу Томосу й автокефалї в украӥнських релігійних медіа лежать когнітивні метафори та метонімії. Метафора та метонімія $\epsilon$ моделями категоризації знань та засобами формування, аргументації та нав'язування цінностей у потенційної аудиторії. До найбільи вживаних когнітивних метафор належать "Церква - тіло", "Релігійні діячі - лікарі", "Міжправославні відносини - війна", "Міжправославні відносини - гра", а до найбільш продуктивної когнітивної метоніміїгеографічна метонімія, за якою суб'єктність переноситься на місиевість. Сферою-донором у когнітивних метафорах для вираження оцінки прочесів, щз відбуваються в міжчерковних відносинах, стає людське тіло, медищина, війна, гра, злочин тощуо. Рішення церковних діячів щуодо Томосу концептуалізуються як 
Актуальні проблеми української лінгвістики: теорія і практика

правильні або неправильні лікувальні дії над хворим тілом, вдалий чи невдалий діагноз лікаря, загарбнищькі військові дії або ж боротьба заради миру, рейдерське захоплення або ж чесна / нечесна гра. В медіатекстах учасників конфлікту з негативними інтенціями вживаються метонімії, в яких Константинопольський патріархат замішується як Фанар або Стамбул, а Московський патріархат - як Москва чи Кремль. У статті зроблено висновок, щзо когнітивні метафори та метонімії вживаються в украӥнському релігійному медіадискурсі з метою впливу на адресатів дискурсу та формування в них необхідної з точки зору адресанта дискурсу "правильної" позищіі щодо Томосу й автокефалії.

Ключові слова: когнітивна метафора, когнітивна метонімія, релігійний медіадискурс, аксіологема, цінності, Томос, автокефалія.

Інформація про автора: Левко Олександр Вадимович кандидат філологічних наук; дочент кафедри загального мовознавства, класичної філології та неоелліністики; Інститут філології; Київський національний університет імені Тараса Шевченка.

Електронна адреса: o.levko@knu.ua.

Левко А.В.

\section{ФОРМИРОВАНИЕ АКСИОЛОГИЧЕСКОГО СТАТУСА ТОМОСА В УКРАИНСКОМ РЕЛИГИОЗНОМ МЕДИАДИСКУРСЕ В СВЕТЕ КОГНИТИВНОЙ ЛИНГВИСТИКИ И РИТОРИКИ}

Аннотация. В статье исследуются когнитивные механизмы формирования аксиологического статуса Томоса и автокефалии Украинской православной церкви в современном украинском религиозном медиадискурсе с точки зрения когнитивной лингвистики и риторики. Материаль исследования - интервью, заявления и другие медиатексты руководителей и спикеров украинских православных иерквей, опубликованные на соответствующих официальных сайтах каждой иерковной юрисдикции по 2018 г.

В результате анализа установлено, что дискуссии в украинских СМИ вокруг вопросов предоставления Томоса Украинской православной иеркви Константинопольским патриархатом дали рождение новым фразеологизмам, например "Страсти по Томосу", "Томос Шредингера", "Томос и Дюерри", и актуализировали 
применения новых для среднестатистической аудитории понятий и слов в украинском медиапространстве, в частности "томос", "автокефалия", "каноничность", "евхаристическое общение", "вселенский патриарх". Определено, что новые для украинских медиа понятия и лексемы получили аксиологическую окраску в СМИ, превратившись из терминов церковного права в аксиологемы или антиаксиологемыл. Было также определено, что в основе аргументации положительного / отрищательного аксиологического статуса Томоса и автокефалии в украинских религиозных медиа лежат когнитивные метафоры и метонимии. Метафора $u$ метонимия являются моделями категоризачии знаний, средствами формирования, аргументации $и$ навязывания иенностей потенциальной аудитории. К наиболее употребляемым когнитивным метафорам принадлежат "Церковь - тело", "Религиозные деятели врачи", "Межправославные отношения - война", "Межправославные отношения - игра", а к наиболее продуктивной когнитивной метонимии - географическая метонимия, в которой субъектность переносится на местность. Для выражения оценки процессов в межиерковных отношениях сферой-донором в когнитивных метафорах становится человеческое тело, медицина, война, игра, преступление. Решения церковных деятелей в отношении Томоса концептуализируются как правильные или неправильные лечебные действия над больным телом, удачный или неудачный диагноз врача, захватнические военные действия или борьба ради мира, рейдерский захват или честная / нечестная игра. В интервью участников конфликта употребляются с негативными интенциями метонимии, в которых Константинопольский патриархат замещается как Фанар или Стамбул, а Московский патриархат - как Москва или Кремль. В статье сделан вывод, что когнитивные метафоры и метонимии используются в украинском религиозном медиадискурсе с иелью воздействия на адресатов дискурса и формирования у них необходимой с точки зрения адресанта дискурса "правильной" позиции в отнотении к Томосу и автокефалии.

Ключевые слова: когнитивная метафора, когнитивная метонимия, религиозный медиадискурс, аксиологема, ценности, Томос, автокефалия.

Информация об авторе: Левко Александр Вадимович кандидат филологических наук; дочент кафедры общего языкознания, классической филологии и неоэллинистики; Институт филологии; Киевский национальный университет имени Тараса Шевченко.

Электронный адрес: o.levko@knu.ua. 
Over the last three decades, Ukrainian religious media discourse has been marked with interconfessional polemics, stemming largely from the presence of several Orthodox jurisdictions, on the one hand, and from discussions over the autocephaly of the Ukrainian Orthodox Church, on the other hand. However, some remarkable political and religious events, such as the 2014 Revolution of Dignity, the War in Donbass, the 2016 PanOrthodox Council in Crete, and particularly the appeal of the President of Ukraine and the Verkhovna Rada to Patriarch of Constantinople to grant Tomos to the Ukrainian Orthodox Church in April 2018 raised the intra-Orthodox polemics to a new level, which has significantly affected Ukrainian religious and secular mass media. A wealth of terms, which used to be unknown to Ukrainian laypeople and not wholly clear even to believers, have pervaded Ukrainian media space, namely Tomos, autocephaly, canonicity, Eucharistic communication, Ecumenical Patriarchate. Mass media battles over these religious processes have given rise to new phraseological units, mostly based on intertextual play, such as "Страсті за Томосом", "Томос Шрьодінгера", "Томос і Джері" etc. Moreover, the above-mentioned words, especially Tomos and Autocephaly, have got axiological connotation in the mass media, turning from the terms of the Church law into axiologemes and antiaxiologemes in the discourse of religious leaders representing different Orthodox jurisdictions. Essentially, the uncertainty of Tomos' and autocephaly's axiological status is what determines the urgency of linguistic studies which would construe these issues through the prism of axiological linguistics, linguopragmatics and new rhetoric. Thus, the purpose of the present study is to identify the role of cognitive metaphors and metonymies in the construction and argumentation of the binary axiological status of Tomos and autocephaly in Ukrainian religious media discourse. The study is based on 30 interviews, public announcements and other media texts of UOC (MP) and UOC (KP) leaders and spokesmen, which have been published on respective official websites of each jurisdiction from May to October 2018. 
Modern cognitive linguistics and rhetoric have revisited the role of rhetorical devices and topoi in text arrangement. While in ancient treatises tropes and figures were regarded merely as ornamental means, in modern cognitive sciences they are viewed as cognitive models, helping the speaker persuade his/her audience at a deeper level of perception, affecting their reasoning processes. Via cognitive mechanisms underlying common rhetorical devices (particularly metaphor, metonymy and antithesis), discourse producers shape the values and beliefs, which they impose on their audience as either persuasive or manipulative endeavor.

Starting with the seminal work "Metaphors We Live By" by G. Lakoff and M. Johnson [18], metaphor has come to be recognized as a universal cognitive model of reception, generation and propagation of new knowledge and concepts about the world. The persuasive and heuristic potential of metaphor is emphasized in the works by P. Ricoeur [8], E. McCormack [6], R. Boyd [12], G. Lakoff [17], A. Denham [14], G. Fauconnier and M. Turner [16], N. Arutiunova [1], V. Teliia [9], V. Gak [3]. As noted by G. Lakoff and M. Johnson, "metaphor is pervasive in everyday life, not just in language, but in thought and action" [18, p. 3]. The authors also attach much importance to the cognitive nature of metonymy, which is no less widespread in common language. Further cognitive studies have proven that not only metaphor and metonymy, but other rhetorical devices as well, serve as modi of thinking, patterns of knowledge categorization and foundation of rhetorical argumentation [15; 11, p. 145-147; 13, p. 123-152].

Studies in the field of media discourse have begun to actively incorporate the concepts and theories of cognitive rhetoric and linguistics. Many authors claim that metaphor plays a key role in media discourse owing to its gnoseological and heuristic functions, on the one hand, and persuasive function, on the other hand $[10 ; 5$; 7]. A. Baranov and Y. Karaulov assert that metaphor is used in the political discourse with the purpose of making the audience take a positive or negative stance toward certain political process or entity [2, p. 189]. In other words, the axiological aspect of using metaphor in argumentation is of critical importance. The same applies to the 
role of cognitive metaphor in the segment of intra-Orthodox relations in religious media discourse, which is the object of our study.

Having analyzed the interviews and announcements of the heads of UOC (MP) and UOC (KP) press services, published on respective official websites from May to October 2018, we found out that metaphor and metonymy are productive cognitive models underlying the reasoning of Church spokesmen and the construction of their argumentation. Apart from the leaders' great authority among the believers, rhetorical means are another crucial factor determining the agreement with or refutation of the official Church position on the issue of Tomos and autocephaly by the believers.

Undoubtedly, media texts of the UOC (KP) spokesmen position Tomos as a great value for the Ukrainian people, which is evident in the high frequency of syntagmatic units "важливість Томосу", "отримання Томосу", "надання Томосу", "чекати на Томос" and phrases of the kind "Томос, який ми очікуємо від Вселенського nатріарха, буде" (CerkvaInfo, 10.10.2018); "Призначення екзархів означає надання томосу, че вже незворотний крок" (CerkvaInfo, 17.09.2018); "Зараз всі чекають томосу" (CerkvaInfo, 17.09.2018); "Томос же надає нам право спілкування із усіма православними церквами" (CerkvaInfo, 10.10.2018).

Contrariwise, the discourse of UOC (MP) spokesmen demonstrates their negative viewpoint on the issue of Tomos in its current state and disapproval of the recent decisions of the Ecumenical Patriarchate. For example, the following statements are aimed at discrediting the mere idea of Tomos and autocephaly for Ukraine: "Те, що сьогодні ведеться багато розмов про Томос, ще не значить, що він принесе нам користь" (NewsChurch, 28.09.2018); "Ми маємо звертати увагу не на Томоси, не на иі безкінечні суперечки: хто перший, хто останній" (NewsChurch, 12.10.2018); "Томос - это вопрос не черковный, это вопрос геополитики, нацбезопасности. Но, извините, не для этого Церковь создавалась" (NewsChurch, 26.09.2018); "А пока что, без создания новой иеркви, даже Томос - это просто бумага" (NewsChurch, 26.09.2018); "Томос обмежить нашу свободу, яку 
ми сьогодні масмо. Якщо комусь потрібно, будь ласка. Нам ие непотрібно" (NewsChurch, 14.09.2018).

In the process of our analysis of the religious media texts we have identified central cognitive metaphors that are used to influence and shape the public opinion on the UOC autocephaly as either a value or antivalue. The most common cognitive metaphors include "Church is body", "Church leaders are doctors", "Intra-Orthodox relations are war", "Intra-Orthodox relations are play". The abovementioned cognitive metaphors actually correlate with the modi of argumentation of the Church stance on the axiological status of Tomos and autocephaly.

Cognitive metaphor "Church is body" can be traced back to Early Christian discourse. In particular, Apostle Paul calls the Church "the body of Christ" (1 Cor. 12:27) or "the body in Christ" (Rom. 12:5). Moreover, he conceptualizes the Church in naturalistic somatic vein so that the believers are associated with certain body parts - eyes, hands, legs etc. (1 Cor. 12:14-26). Overall, "the image of body for a community, characterized with closedness and organic growth, is common to the ancient tradition" [4].

In the texts under study, cognitive metaphor "Church is body" is used in quite different ways in the statements and interviews of UOC (MP) spokesmen, on the one hand, and UOC (KP) spokesmen, on the other hand. However, common to the discourse of both parties is the initial idea of the schism as a wound of the Church that badly needs treatment. Thus, the basic source domain of the metaphors used to evaluate the current processes in intra-Orthodox relations is medicine. The decisions of Church figures regarding Tomos and autocephaly are therefore imaged as either right or wrong treatment for a wounded body. Actually, this is the way in which a more specific cognitive metaphor "Church leaders are doctors" is represented in their discourse. The following statements serve to exemplify it:

"Найнебезпечніме, що міститься в ріменнях вчорашнього Синоду Константинопольської Патріархї, ие породження ще одного иерковного розколу. Звичайно, що таке 
Актуальні проблеми української лінгвістики: теорія і практика

рімення не об'єднас православних, не зцілить рану розколу" (NewsChurch, 12.10.2018);

"Патріарх змінив свою думку і свойми діями ранить тіло канонічної Церкви в Украӥні" (NewsChurch, 13.09.2018);

"Патріарх Варфоломій у намому випадку поставив помилковий діагноз $i$ продовжує здійснювати помилкове лікування" (NewsChurch, 13.09.2018);

"Наполегливі й уперті спроби Вселенського Патріархату зцілити розкол в Україні шляхом надання автокефалії не $\boldsymbol{\epsilon}$ ліками, а отрутою як для канонічної Украӥнської Православної Церкви, так $і$ для всього Тіла Вселенського Православ'я" (NewsChurch, 13.09.2018).

Cognitive metaphors "Church is body" and "Church leaders are doctors" in UOC (MP) media texts serve to create the image of Constantinople's Patriarch Bartholomew as a bad doctor who "prescribed" Tomos to the Church as a wrong treatment, which would eventually poison it instead of curing the wound of schism. Obviously, in this case metaphorization from the field of medicine has as its goal discrediting the idea of Tomos and granting autocephaly to the Church in the format offered by the Ecumenical Patriarchate.

While UOC (KP) spokesmen use identical cognitive model of imaging intra-Orthodox relations as medical procedures, they present Tomos as the right treatment for overcoming the schism and restoring Orthodox unity: "Томос - це зиивання рани. А те, що зиите, повинно ще зростись" (CerkvaInfo, 10.10.2018); "Бо зрозуміло, що, з одного боку, ие питання [иерковне], яке має бути вирімене, $i$ чим далі його відкладати, тим проблем буде лише більше. Це як лікування зуба: коли зуб заболів, можна вжити таблетку, можна відкладати, але рано чи пізно доведеться йти до дантиста. I чим пізніше йти, тим гірше буде, тим складніше буде" (CerkvaInfo, 15.09.2018). Putting obstacles in the path of the Church's receiving Tomos is associated with the actions that will only prevent wound healing: "А якщо рану постійно посипати сіллю, то вона не зростеться" (CerkvaInfo, 10.10.2018). 
Pervasive in the discourse of UOC (MP) and UOC (KP) spokesmen is also the cognitive metaphor "Intra-Orthodox relations are war". Their statements create the negative image of Constantinople's Patriarch Bartholomew as an enemy, whose actions regarding the UOC autocephaly are associated with military invasion, provocation or even annexation of the "canonical territory", e.g.:

"Наслідок иього кроку Вселенського Патріарха вплине на все Православ'я, тому що, якщо один Патріарх вторгається на канонічну територію іншої Церкви, то чому тоді не може робити це й іниий?... Це же буде катастрофа" (NewsChurch, 13.09.2018);

"Усе залежить від того, як далеко підуть представники Константинопольського патріархату на канонічній території УПЦ" (NewsChurch, 13.09.2018);

"Але час дипломатії вже минув, $i$ треба говорити відкрито і відверто, тому що небезпека загрожує всьому Православ'ю" (NewsChurch, 13.09.2018);

"Константинополь регламентуе свою агресивну політику відносно Украӥни" (NewsChurch, 12.10.2018);

"...Не станет ли эта речь Патриарха Варфоломея идеологическим обоснованием для "Варфоломеевской ночи" в Украине?" (NewsChurch, 06.09.2018).

For UOC (KP), on the other hand, the "ideal enemy" is Patriarch Kirill, with his actions being represented as hostile to Orthodox unity, e.g.:

"Бо українська церква буде союзна з Константинополем, $i$ це буде не "війна" греків зі слов'янами (як Москва це намагається подавати зараз), а ие буде "війна" тих, хто хоче зруйнувати єдність православ'я заради імперських амбічій Кремля, з тими, хто хоче зберегти єдність православ'я і рухати його в майбутне" (CerkvaInfo, 15.09.2018);

"Виключити з иього прочесу Патріарха Філарета...- ие буде остання барикада, яку буде намагатися втримати Патріарх Кирил" (CerkvaInfo, 28.08.2018);

"Це вже буде битва сдиної православної вселенської Церкви з московськими амбіиіями" (CerkvaInfo, 30.08.2018). 
Another way in which the UOC (MP) spokesmen shape the negative judgment of Constantinople patriarchate's decisions in the public is positioning their actions as illegal. To be more precise, the actions of Patriarch Bartholomew are labeled as anti-canonical, i.e. violating the Church law (to a certain extent, canons in interconfessional relations correlate with international law). The actions of Patriarch Bartholomew are presented as ones that discredit canonicity - a significant value for Orthodox discourse, which, however, is often misused in religious mass media. In UOC (MP) media texts, the actions of Patriarch of Constantinople are occasionally metaphorically portrayed as criminal offences, with the lexis being borrowed from criminal law to construct the negative axiological status of Tomos, e.g.:

"Константинополь прийняв таке рішення, однак, за великим рахунком, ие рішення означає рейдерське захоплення всіх церковних приміщень, всього церковного майна на території Української Православної Церкви" (NewsChurch, 12.10.2018);

"I навіть вони претендують на наме майно. Тепер вони все оголосили своєю власністю. Це я б назвав безпрецедентним шахрайством, як воно виглядає збоку для пересічних громадян" (NewsChurch, 12.10.2018).

Occasionally used in media discussions around Tomos is also less salient cognitive metaphor "Intra-Orthodox relations are play", which likewise helps the Church spokespeople discredit their opponents in the eyes of the public, e.g.:

"Москва любила і любить грати на внутрішніх грецьких протиріччях. На суперечках між Афоном $i$ офіційною Елладською Церквою" (CerkvaInfo, 29.08.2018);

"I Вселенський Патріархат грає на боці ворогів намої Церкви" (NewsChurch, 13.09.2018);

"Константинополь з позиції арбітра, який стоїть над всією битвою, стає одним з ї̈ учасників" (CerkvaInfo, 30.08.2018);

Apart from cognitive metaphor, the texts under study are interspersed with metonymy, which in this case is aimed at affecting 
the public opinion on the axiological status of Tomos and autocephaly and making the audience take the "right" stance, as they see it. The most common in religious media texts is geographical metonymy, whereby agency is transferred to location. More specifically, the actions of Patriarch Bartholomew are often presented as the actions of Constantinople owing to his official title (i.e. in a rather neutral tone) or as the actions of Fanar or even Istanbul, which conveys the intention to discredit Patriarch Bartholomew and his administration. The deprecatory effect of the latter kind of metonymy is explained by the fact that Fanar is only a small region in Istanbul, where the residence of the Ecumenical Patriarchate is located. The fall of Constantinople and the renaming of the city into Istanbul is still a sore subject to the Greeks inhabiting it. In UOC (KP) media texts presentation of Moscow Patriarchate's actions as the actions of Moscow or Kremlin pursues the same communicative goal, namely discrediting and disparaging the decisions of the opponent. Here are a few examples illustrating the use of this technique in the discussion of Tomos: "Я не знаю, чому на Фанарі забули про інші подї 20-х років, коли турещьке керівництво створювало Турецьку православну иеркву" (NewsChurch, 18.09.2018); "Неужели на Фанаре надеются, что Филарет снимет свой патриарший куколь?" (NewsChurch, 13.10.2018); "Москва готова віддати свою митрополію в юрисдикиію Константинополя?" (CerkvaInfo, 30.08.2018); "Протистоянь хоче Москва, вона їх вигадує навіть там, де їх не існує" (CerkvaInfo, 17.09.2018); "Це законне місие Вселенського патріарха, а Москва каже: тепер ми найбільша церква" (CerkvaInfo, 10.10.2018).

To recapitulate, as a result of our study we can conclude that discussion around Tomos and autocephaly in religious mass media have brought about the appearance of new phraseological units and actualization of specifically religious terms in Ukrainian media space. Such words as Tomos, autocephaly, canonicity, Eucharistic communication have acquired axiological connotations, going way beyond their functioning as neutral terms in the Church law. We have found out that the argumentation of positive / negative 
axiological status of Tomos and autocephaly in religious mass media is marked with abundant use of cognitive metaphors and metonymies. In this respect, the most common cognitive metaphors are "Church is body", "Church leaders are doctors", "Intra-Orthodox relations are war", "Intra-Orthodox relations are play", while the most salient cognitive metonymy is geographical metonymy, whereby the agency is transferred to location. The above-mentioned models, being rhetorical inasmuch as cognitive, are intended to sway the audience towards taking the side of the addresser in the discussion around the value of Tomos and autocephaly for Ukraine.

\section{REFERENCES}

1. Arutiunova N.D. Metaphor [Metafora]. Lingvisticheskii entsiklopedicheskii slovar / pod red. V.N. Yartsevoi. Moskva: Sov. entsikl.,1990. S. 296-297.

2. Baranov A.N., Karaulov Yu.N. Russian Political Metaphor (Materials for the Dictionary) [Russkaia politicheskaia metafora (materialy k slovariu)]. Moskva: Institut russkogo yazyka AN SSSR, 1991. $193 \mathrm{~s}$.

3. Gak V.G. Metaphor: universal and specific [Metafora : universalnoie i spetsificheskoie]. Metafora v yazyke i tekste / pod red. V. N. Teliia. Moskva : Nauka, 1988.S. 11-26.

4. Ivliev I. Christ's Church in the Epistles of Saint Apostle Paul [Tserkov Khristova v poslaniiah sviatogo apostola Pavla]. Alfa i Omega. 2004. № 39. S. 13-24.

5. Kaltashkina E.Yu. The Role and Meaning of the Conceptual Metaphor in the British Political Media Discourse [Rol i znacheniie kontseptualnoi metafory $\mathrm{v}$ britanskom politicheskom media-diskurse]. Vestnik Cheliabinskogo gosudarstvennogo universiteta. Seriia : Filologiia. Iskusstvovedeniie. 2012. Vyp. 70. S. 74-79.

6. MacCormac E.A Cognitive theory of metaphor [Kognitivnaia teoriia metafory]. Teoriia metafory : sbornik / pod red. N.D. Arutiunovoi i M.A. Zhurinskoi. Moskva : Progress, 1990. S. 358-386.

7. Odynetska L.V. The role of the metaphor in mass media [Rol metafory $\mathrm{v}$ zasobakh masovoi informatsii]. Aktualni problemy teorii sotsialnykh komunikatsii : Zbirnyk naukovykh prats. Kyiv, 2017. S. 44-48.

8. Ricoeur P. The metaphorical process as cognition, imagination, and feeling [Metaforicheskii protsess kak poznaniie, voobrazheniie i oschuscheniie]. Teoriia metafory : sbornik / pod red. N.D. Arutiunovoi i M.A. Zhurinskoi. Moskva : Progress, 1990. S. 416-434. 
9. Teliia V. N. Metaphorization and its role in the construction of language picture of the world [Metaforizatsiia $\mathrm{i}$ eio rol $\mathrm{v}$ sozdanii yazykovoi kartiny mira]. Rol chelovecheskogo faktora $v$ yazyke. Yazyk $i$ kartina mira / pod red. B.A. Serebrennikova. Moskva: Nauka, 1988. S. 173-203.

10. Chudinov A.P. Russia in the metaphorical mirror : a cognitive research of the politic metaphor [Rossiia $\mathrm{v}$ metaforicheskom zerkale: kognitivnoie issledovaniie politicheskoi metafory]. Ekaterinburg, 2001. $238 \mathrm{~s}$.

11. Bonnefille S. A cognitive rhetoric approach to two political speeches. Anglophonia / Sigma : French Journal of English Linguistics. 2011. Vol. 15 (30). P. 145-162.

12. Boyd R. Metaphor and theory change : What is "metaphor" a metaphor for? Metaphor and Thought : 2nd edition. New York : Cambridge University Press, 1993. P. 481-532.

13. Browse S. Cognitive Rhetoric : The Cognitive Poetics of Political Discourse. Amsterdam ; Philadelphia : John Benjamins Publishing Company, 2018. 247 p.

14. Denham A. Metaphor and Moral Experience. Oxford : Clarendon Press, 2000. $376 \mathrm{p}$.

15. Fahnestock J. Rhetoric in the Age of Cognitive Science. The Viability of Rhetoric / ed. R. Graff. New York: State University of New York Press, 2005. P. 159-179.

16. Fauconnier G. \& Turner M. Rethinking Metaphor. Cambridge Handbook of Metaphor and Thought / ed. R. Gibbs. New York : Cambridge University Press, 2008. P. 53-66.

17. Lakoff G. The Contemporary Theory of Metaphor. Metaphor and Thought : 2nd edition. New York : Cambridge University Press, 1993. P. 202-255.

18. Lakoff G. \& Johnson M. Metaphors We Live By. Chicago : University Of Chicago Press, 1980. 256 p.

\section{RESOURCES}

NewsChurch - The Synodal information and educational Department of the UOC [Synodalnyi Informatsiino-prosvitnytskyi viddil UPTs] (http://news.church.ua/).

CerkvaInfo - Official site of Ukrainian Orthodox Church of Kyiv Patriarchate [Ofitsiinyi sait Ukrainskoi Pravoslavnoi Tserkvy Kyivskoho Patriarkhatu] (http://www.cerkva.info/). 


\section{ЛІТЕРАТУРА}

1. Арутюнова Н.Д. Метафора. Лингвистический энииклопедический словарь / под ред. В. Н. Ярцевой. Москва : Сов. энцикл., 1990. С. 296-297.

2. Баранов А.Н., Караулов Ю.Н. Русская политическая метафора (материалы к словарю). Москва : Институт русского языка АН СССР, $1991.193 \mathrm{c}$.

3. Гак В.Г. Метафора : Универсальное и специфическое. Метафора в языке и тексте / под ред. В.Н. Телия. Москва : Наука, 1988. С. 11-26.

4. Ивлиев И. Церковь Христова в Посланиях святого апостола Павла. Альфа и Омега. 2004. № 39. С. 13-24.

5. Калташкина Е. Ю. Роль и значение концептуальной метафоры в британском политическом медиа-дискурсе. Вестник Челябинского государственного университета. Серия : Филология. Искусствоведение. 2012. Вып. 70. С. 74-79.

6. МакКормак Э. Когнитивная теория метафоры. Теория метафоры: сборник / под ред. Н.Д. Арутюновой и М.А. Журинской. Москва : Прогресс, 1990. С. 358-386.

7. Одинецька Л.В. Роль метафори в засобах масової інформації. Актуальні проблеми теорї соціальних комунікацій : Збірник наукових праць. Київ, 2017. С. 44-48.

8. Рикёр П. Метафорический процесс как познание, воображение и ощущение. Теория метафоры : сборник / под ред. Н.Д. Арутюновой и М.А. Журинской. Москва : Прогресс, 1990. С. $416-434$.

9. Телия В. Н. Метафоризация и её роль в создании языковой картины мира. Роль человеческого фактора в языке. Язык и картина мира / под ред. Б.А. Серебренникова. Москва : Наука, 1988. C. $173-203$.

10. Чудинов А.П. Россия в метафорическом зеркале : когнитивное исследование политической метафоры. Екатеринбург, $2001.238 \mathrm{c}$.

11. Bonnefille S. A cognitive rhetoric approach to two political speeches. Anglophonia / Sigma : French Journal of English Linguistics. 2011. Vol. 15 (30). P. 145-162.

12. Boyd R. Metaphor and theory change : What is "metaphor" a metaphor for? Metaphor and Thought : 2nd edition. New York : Cambridge University Press, 1993. P. 481-532. 
13. Browse S. Cognitive Rhetoric : The Cognitive Poetics of Political Discourse. Amsterdam ; Philadelphia : John Benjamins Publishing Company, 2018. $247 \mathrm{p}$.

14. Denham A. Metaphor and Moral Experience. Oxford : Clarendon Press, 2000. 376 p.

15. Fahnestock J. Rhetoric in the Age of Cognitive Science. The Viability of Rhetoric / ed. R. Graff. New York: State University of New York Press, 2005. P. 159-179.

16. Fauconnier G. \& Turner M. Rethinking Metaphor. Cambridge Handbook of Metaphor and Thought / ed. R. Gibbs. New York : Cambridge University Press, 2008. P. 53-66.

17. Lakoff G. The Contemporary Theory of Metaphor. Metaphor and Thought : 2nd edition. New York : Cambridge University Press, 1993. P. 202-255.

18. Lakoff G. \& Johnson M. Metaphors We Live By. Chicago : University Of Chicago Press, 1980. 256 p.

\section{ДЖЕРЕЛА}

NewsChurch - Синодальний інформаційно-просвітницький відділ УПЦ (http://news.church.ua/).

CerkvaInfo - Офіційний сайт Української Православної Церкви Київського Патріархату (http://www.cerkva.info/).

$$
\begin{aligned}
& \text { Дата надходження до редакції - 12.10.2018 p. } \\
& \text { Дата затвердження редакцісю - 19.11.2018 p. }
\end{aligned}
$$

УДК $81 ’ 42: 17.022 .1$

DOI: https://doi.org/10.17721/APULTP.2018.37.105-124

Olga M. Pliasun

\section{THE CATEGORY OF IMAGE IN LINGUISTIC DISCOURSE}

Abstract. The article aims to give a comprehensive account of innovative theoretical developments in the field of linguistic imageology. The main objective of the paper is the linguistic analysis of the category of 